\title{
Biochemical signs of impaired cobalamin function do not affect hematological parameters in young infants: results from a double-blind randomized controlled trial
}

\author{
Håvard Bjørke Jenssen ${ }^{1}$, Ingrid Torsvik2 ${ }^{2}$ Per Magne Ueland ${ }^{3,4}, \varnothing$ ivind Midttun ${ }^{5}$ and Anne-Lise Bjørke-Monsen ${ }^{3}$
}

BACKGROUND: Whereas iron deficiency is considered the leading cause of anemia in infants, cobalamin deficiency is foremost characterized by developmental delay, and the typical macrocytic anemia is confined to severe and longstanding cobalamin deficiency in this age group. Hematological parameters were investigated in 4-mo-old infants with biochemical signs of impaired cobalamin function who participated in a randomized controlled cobalamin intervention study at 6 wk.

METHODS: One hundred and seven infants were randomly assigned to receive either an intramuscular injection with $400 \mu \mathrm{g}$ cobalamin or no intervention at 6 wk. Hematological parameters, and cobalamin and folate status were determined at inclusion and $4 \mathrm{mo}$.

RESULTS: Cobalamin supplementation improved all markers of impaired cobalamin function but had no effect on hematological cell counts at 4 mo $(P>0.18)$. Signs indicative of an iron-restricted erythropoiesis were observed at $6 \mathrm{wk}$ and $4 \mathrm{mo}$. At $4 \mathrm{mo}$, the strongest predictors of low iron status were male gender and a high percentage weight increase from birth.

CONCLUSION: In infants with biochemical signs of impaired cobalamin function, supplementation does not improve hematological cell counts. Variations in erythrocyte parameters seem to be foremost associated with iron status in this age group.

infon nfancy is a period characterized by rapid growth with increased demands of several micronutrients and a subsequent risk of nutritional deficiency (1). In mainly breastfed infants, both iron and cobalamin deficiency are reported to be prevalent $(1,2)$. Whereas iron deficiency is considered the leading cause of anemia in infants (3), cobalamin deficiency is foremost characterized by developmental delay in this age group $(2,4)$. Infants with marginal cobalamin deficiency are reported to have normal hematological values $(5,6)$, and pancytopenia and macrocytic anemia are mainly observed in severe and longstanding cobalamin deficiency (2).

Nutritional evaluation in infants may be difficult due to the extensive physiological changes occurring during the first months of life, complicating the interpretation of ordinary laboratory parameters $(2,7)$. Serum cobalamin decreases substantially during the first weeks and remains low the first $6 \mathrm{mo}$, whereas serum folate increases and remains high throughout the first year of life (8). These changes are accompanied by an increase in the metabolic markers total homocysteine (tHcy) and methylmalonic acid (8). Cobalamin supplementation changes all markers of impaired cobalamin status toward a profile observed in cobalamin-replete older children and adults, implying that the high tHcy and methylmalonic acid levels reported in a large fraction of mainly breastfed infants do not reflect immature metabolism but rather insufficient cobalamin to fully sustain cobalamin-dependent reactions (9).

The rate of hemoglobin synthesis and erythrocyte production decreases dramatically during the first days after birth and reaches a minimum during the second week of life. Due to a suppressed erythropoiesis and a reduced life span of fetal erythrocytes $(60-70 \mathrm{~d})$, the hemoglobin $(\mathrm{Hb})$ level and the erythrocyte count reach their lowest values $\sim 2$ mo after birth $(10,11)$. The size of the erythrocyte, determined by mean cellular volume (MCV), decreases and is smallest at 6 mo of age, thereafter gradually increasing (10). Whereas ordinary red cell parameters, such as $\mathrm{Hb}$ level and MCV, reflect mean values of an erythrocyte population with an average life span of $120 \mathrm{~d}$, reticulocyte hemoglobin content $(\mathrm{CHr})$ provides a real-time evaluation of the erythropoiesis in the preceding $24-48 \mathrm{~h}$ (12). This advantage makes $\mathrm{CHr}$ useful during periods with rapid physiological changes, and it has been suggested that $\mathrm{CHr}$ is the best predictor of iron deficiency in infants and is superior to traditional iron parameters such as serum ferritin and transferrin saturation (7).

We have previously conducted a randomized controlled cobalamin intervention trial in mainly breastfed infants aged $6 \mathrm{wk}$ with biochemical signs of impaired cobalamin function (9). In this article, we report on the effect of cobalamin supplementation on hematological parameters in the infants at $4 \mathrm{mo}$. The purpose of this study was to examine whether the metabolic profile indicating impaired cobalamin function was

${ }^{1}$ Royal College of Surgeons in Ireland, Dublin, Ireland; ${ }^{2}$ Department of Pediatrics, Haukeland University Hospital, Bergen, Norway; ${ }^{3}$ Laboratory for Clinical Biochemistry, Haukeland University Hospital, Bergen, Norway; ${ }^{4}$ Institute of Medicine, University of Bergen, Bergen, Norway; ${ }^{5}$ Bevital AS, Bergen, Norway. Correspondence: Anne-Lise Bjørke-Monsen (almo@helse-bergen.no) 
Table 1. Demographic data of infants and mothers at $6 \mathrm{wk}$ and $4 \mathrm{mo}$

\begin{tabular}{lcc}
\hline Infant data & $6 \mathrm{wk}$ & 4 mo \\
\hline Number & 107 & 102 \\
Weight, g, mean (SD) & $4,946(681)$ & $6,936(821)$ \\
Nutrition, $n$ (\%) & & \\
$\quad$ Exclusively breastfed & $86(80 \%)$ & $71(70 \%)$ \\
$\quad$ Weaning to food & 0 & $14(14 \%)$ \\
$\quad$ Vitamin supplementation & $1(1 \%)$ & $2(2 \%)$ \\
$\begin{array}{l}\text { Maternal data } \\
\text { Number }\end{array}$ & 104 & 99 \\
$\begin{array}{l}\text { BMI, mean (SD) } \\
\text { Daily use of vitamin } \\
\text { supplementation, } n \text { (\%) }\end{array}$ & $25.2(3.9)$ & $24.6(4.0)$ \\
$\begin{array}{l}\text { Daily use of iron } \\
\text { supplementation, } n \text { (\%) }\end{array}$ & $36(34 \%)$ & $37(37 \%)$ \\
Daily smoking, $n$ (\%) & $28(27 \%)$ & $15(15 \%)$ \\
\hline
\end{tabular}

associated with hematological cell line production during the first months of life.

\section{RESULTS}

\section{Demographics and Nutrition}

The study group included 107 healthy, 6-wk-old infants, 56 boys (52\%), born at term (mean gestational age 39.9 (SD 1.3) wk), with an appropriate-for-gestational-age weight (mean 3,578 (SD 506) g). There were no significant differences between the cobalamin and control group according to demographic characteristics of infants and mothers at inclusion and follow-up $(P$ $>0.05)$, and data for the total group are presented in Table 1 . Two different kinds of milk formula were used, both enriched with iron $(0.7-0.8 \mathrm{mg}$ per $100 \mathrm{ml}$ of prepared milk formula) and cobalamin $(0.13-0.2 \mu \mathrm{g}$ per $100 \mathrm{ml}$ of prepared milk formula). Various kinds of porridge were used, all enriched with iron (4.8-11.1 mg per $100 \mathrm{mg}$ powder). No infant received iron supplementation.

Mean percentage weight increase from birth was 39\% (SD $14 \%$ ) at $6 \mathrm{wk}$ and $95 \%$ (SD 26\%) at 4 mo. By Spearman correlation percentage weight increase at $6 \mathrm{wk}(r=-0.44, P<0.001)$ and at $4 \mathrm{mo}(r=-0.57, P<0.001)$ were inversely correlated to birth weight. No significant differences in percentage weight increase or in feeding pattern were observed between girls and boys at $6 \mathrm{wk}$ and $4 \mathrm{mo}(P>0.06)$.

Mean maternal age was 31.5 (SD 4.8) y, and 63 of the 104 mothers were multiparous, and had a mean number of 1.4 (range: 1-4) prior children. Daily use of iron supplementation for shorter or longer periods during pregnancy was reported by 38 of 104 mothers. Two of the mothers were vegetarians, and the others reported having an omnivorous diet, although nine mothers reported that they rarely or never ate meat $(n=$ $6)$ or fish $(n=3)$.

\section{Infant Cobalamin and Folate Status}

A detailed description of cobalamin and folate status has been published (9). At $6 \mathrm{wk}$, the median serum cobalamin level was
Table 2. Hematological parameters according to intervention at $6 \mathrm{wk}$ and $4 \mathrm{mo}$

\begin{tabular}{|c|c|c|c|c|}
\hline & & $\begin{array}{l}\text { Cobalamin } \\
\text { group }\end{array}$ & $\begin{array}{l}\text { Control } \\
\text { group }\end{array}$ & $P$ value \\
\hline \multirow[t]{2}{*}{$N$} & $6 w k$ & 54 & 53 & \\
\hline & $4 \mathrm{mo}$ & 52 & 50 & \\
\hline \multirow{3}{*}{$\begin{array}{l}\text { Hemoglobin, } \\
\text { g/dl }\end{array}$} & $6 w k$ & $13.1(2.1)$ & $12.9(1.6)$ & 0.67 \\
\hline & $4 \mathrm{mo}$ & $12.0(0.8)$ & $12.1(1.0)$ & 0.33 \\
\hline & $P$ value ${ }^{b}$ & 0.001 & 0.004 & \\
\hline \multirow{3}{*}{$\begin{array}{l}\text { Erythrocytes, } \\
\times 10^{12} /\end{array}$} & $6 w k$ & $4.00(0.60)$ & $4.00(0.42)$ & 0.89 \\
\hline & $4 \mathrm{mo}$ & $4.33(0.32)$ & $4.42(0.39)$ & 0.24 \\
\hline & $P$ value ${ }^{b}$ & $<0.001$ & $<0.001$ & \\
\hline \multirow{3}{*}{$\begin{array}{l}\text { Mean cellular } \\
\text { volume, } \mathrm{fl}\end{array}$} & $6 w k$ & $96.5(4.6)$ & $95.9(4.5)$ & 0.52 \\
\hline & $4 \mathrm{mo}$ & $82.7(3.4)$ & $82.3(3.6)$ & 0.58 \\
\hline & $P$ value ${ }^{b}$ & $<0.001$ & $<0.001$ & \\
\hline \multirow{3}{*}{$\begin{array}{l}\text { Reticulocytes, } \\
\times 10^{12} / /^{c}\end{array}$} & $6 w k$ & $0.041(0.019)$ & $0.042(0.020)$ & 0.78 \\
\hline & $4 \mathrm{mo}$ & $0.060(0.013)$ & $0.057(0.013)$ & 0.99 \\
\hline & $P$ value ${ }^{b}$ & 0.001 & $<0.001$ & \\
\hline \multirow{3}{*}{$\begin{array}{l}\text { Reticulocyte } \\
\text { hemoglobin } \\
\text { content, pgc }\end{array}$} & $6 w k$ & $31.9(1.5)$ & $32.1(1.6)$ & 0.61 \\
\hline & $4 \mathrm{mo}$ & $29.6(1.4)$ & $29.6(1.4)$ & 0.53 \\
\hline & $P$ value ${ }^{b}$ & $<0.001$ & $<0.001$ & \\
\hline \multirow{3}{*}{$\begin{array}{l}\text { Leukocytes, } \\
\times 10^{9} / /\end{array}$} & $6 w k$ & $8.8(1.9)$ & $9.0(2.3)$ & 0.54 \\
\hline & $4 \mathrm{mo}$ & $9.5(2.7)$ & $9.5(2.8)$ & 0.59 \\
\hline & $P$ value ${ }^{b}$ & 0.020 & 0.28 & \\
\hline \multirow{3}{*}{$\begin{array}{l}\text { Platelets, } \times \\
10^{9} / 1\end{array}$} & $6 w k$ & $438(137)$ & $482(123)$ & 0.08 \\
\hline & $4 \mathrm{mo}$ & $519(127)$ & $516(107)$ & 0.93 \\
\hline & $P$ value $^{\mathrm{b}}$ & 0.001 & 0.15 & \\
\hline
\end{tabular}

aStudent's $t$-test, group statistics. ${ }^{b S}$ Student's $t$-test; paired samples. 'Reticulocyte data were available for 63 infants at 6 wk (29 girls and 34 boys) and 74 infants at 4 mo (34 girls and 40 boys).

170 (134-255) pmol/l and median plasma tHcy was 7.59 (6.21-9.28) $\mu \mathrm{mol} / \mathrm{l}$; no significant differences in vitamin and metabolite levels were observed between the cobalamin and control group. At 4 mo, the cobalamin group had a $75 \%$ higher median serum cobalamin level as compared with the control group, and their median tHcy level was reduced by $39 \%$ but remained unchanged in the controls, indicating a metabolic response to cobalamin supplementation.

\section{Infant Hematological Parameters}

Mean $\mathrm{Hb}$ level, MCV, and $\mathrm{CHr}$ decreased from 6 wk to $4 \mathrm{mo}$, whereas the mean number of all three cell lines increased; we observed no significant differences between the cobalamin and the control group (Table 2). Neither did we see any effect of cobalamin supplementation on hematological parameters $(P>0.18$ for all parameters, data not shown) when using a multiple linear regression model, which in addition included gender, percentage weight gain, nutrition, and maternal use of iron supplements (Table 3). At 4 mo, high postnatal percentage weight gain and male gender were the main determinants of hematological parameters and associated with a lower iron status, as determined by MCV and $\mathrm{CHr}$ (Table 3). 
No significant predictors were observed for $\mathrm{Hb}$ level at 4 mo. Generalized additive model illustrations of the dose-response changes in $\mathrm{CHr}$ and $\mathrm{MCV}$ with percentage weight gain are shown in Figure 1. Males had significantly smaller erythrocytes and lower $\mathrm{CHr}$ as compared with girls both at $6 \mathrm{wk}$ and 4 mo (Table 4).

At $6 \mathrm{wk}$, reticulocytosis was inversely associated with $\mathrm{Hb}$ level ( $r=-0.62, P<0.001$, by Spearman correlation), MCV $(r=$ $-0.63, P<0.001)$, and $\mathrm{CHr}(r=-0.54, P<0.001)$ in the combined group, as illustrated by the generalized additive model in Figure 2. Reticulocytosis at $6 \mathrm{wk}$ was also inversely associated with MCV and CHr at $4 \mathrm{mo}(r=-0.55$ and $r=-0.33, P \leq 0.01)$, whereas no significant associations were seen between reticulocytosis at 4 mo and red cell parameters $(P>0.06)$.

\section{DISCUSSION}

In predominantly breastfed, term infants with a biochemical profile indicative of impaired cobalamin function, cobalamin supplementation at $6 \mathrm{wk}$ had a profound effect on metabolic

Table 3. Determinants of erythrocyte parameters in infants at 4 mo by multiple linear regression

\begin{tabular}{|c|c|c|c|c|c|c|}
\hline \multirow{2}{*}{$\begin{array}{l}\text { Independent } \\
\text { variable }\end{array}$} & \multicolumn{2}{|c|}{$\begin{array}{l}\text { Mean cellular } \\
\text { volume (fl) }\end{array}$} & \multicolumn{2}{|c|}{$\begin{array}{l}\text { Reticulocyte } \\
\text { hemoglobin } \\
\text { content (pg) }\end{array}$} & \multicolumn{2}{|c|}{$\begin{array}{l}\text { Hemoglobin } \\
\qquad(\mathrm{g} / \mathrm{dl})\end{array}$} \\
\hline & $B$ & $P$ & $B$ & $P$ & $B$ & $P$ \\
\hline Gender (girl, boy) & -2.4 & $<0.001$ & -0.55 & 0.09 & 0.21 & 0.28 \\
\hline $\begin{array}{l}\text { Percentage } \\
\text { weight increase, } \\
\text { quartiles }^{\text {a }}\end{array}$ & -0.6 & 0.05 & -0.48 & 0.002 & -0.07 & 0.40 \\
\hline $\begin{array}{l}\text { Cobalamin } \\
\text { intervention } \\
\text { (no, yes) }\end{array}$ & 0.4 & 0.50 & 0.04 & 0.90 & -0.21 & 0.27 \\
\hline \multicolumn{7}{|c|}{$\begin{array}{l}\text { The regression model contained infant nutrition (exclusively breastfed vs. } \\
\text { nonexclusively breastfed/formula-fed) and maternal use of iron supplements from } \\
6 \text { wk to } 4 \text { mo (no, yes) as independent variables in addition to the parameters listed in } \\
\text { the table. } B \text { : regression coefficient. }\end{array}$} \\
\hline \multicolumn{7}{|c|}{$\begin{array}{l}\text { a Percentage weight increase from birth to } 4 \text { mo, quartiles: }<79 \%, 79-93 \%, 93-109 \% \text {, } \\
>109 \% \text {. }\end{array}$} \\
\hline
\end{tabular}

a

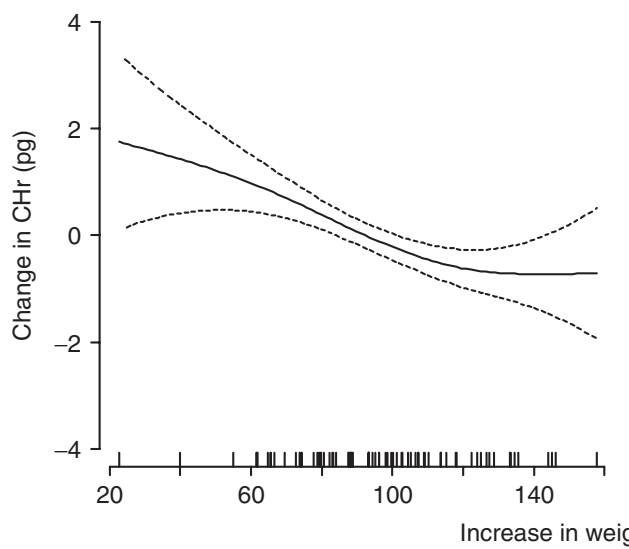

markers of cobalamin status (9) but no effect on hematological parameters at $4 \mathrm{mo}$. A high postnatal percentage weight gain and male gender were the main determinants of hematological parameters and were associated with a lower iron status. Reticulocytosis was associated with a low $\mathrm{MCV}$ and $\mathrm{CHr}$ at both $6 \mathrm{wk}$ and $4 \mathrm{mo}$, demonstrating the existence of an ironrestricted erythropoiesis during the first months of life in mainly breastfed infants.

Formal limitations to the study design included lack of blinding of the investigators and the mothers to the cobalamin injection and a lack of placebo injection in the control group. However, we do not consider these factors important for hematological outcome in the infants at $4 \mathrm{mo}$.

Microbiological assays were used for the determination of both serum folate and cobalamin. In recent years, competitive-binding luminescence assays have been more commonly used, but the microbiologic assay is still considered the gold standard for serum folate (13). Whereas the microbiological assay determines biologically active cobalamin, the competitive-binding luminescence assays also include functionally inactive cobalamin analogs. Recent studies have suggested that the competitive-binding luminescence assays may have widespread malfunction, especially by giving false-normal values in cobalamin deficiency (14).

Cobalamin supplementation normalized markers of cobalamin status and was associated with lower serum folate levels, possibly due to a reduced inhibition of the cobalamin-dependent enzyme methionine synthase, i.e., so-called methyl-folate trapping $(15,16)$. Cobalamin deficiency in infants has been associated with tHcy levels above $12 \mu \mathrm{mol} / \mathrm{l}$ (5). In the cobalamin-supplemented infants at $4 \mathrm{mo}$, the 97.5 percentile for plasma tHcy was $6.50 \mu \mathrm{mol} / \mathrm{l}$, and at $6 \mathrm{wk}, 68 \%$ of the infants had a plasma tHcy above this level (median plasma tHcy 7.59 (interquartile range: 6.21-9.28) $\mu \mathrm{mol} / \mathrm{l}$ ), and a median serum cobalamin level of 170 (interquartile range: 134-255) pmol/l, i.e., a biomarker profile indicating impaired cobalamin function (9). However, cobalamin supplementation did not improve hematological parameters in these infants. The

b

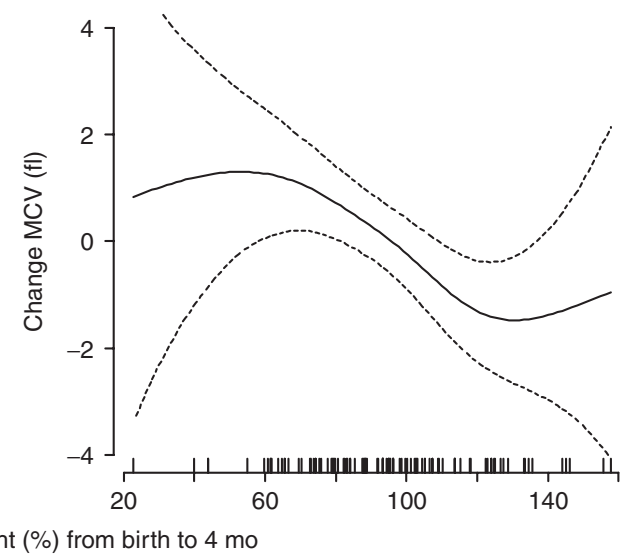

Figure 1. Dose-response relationship between percentage weight gain from birth to 4 mo with (a) reticulocyte hemoglobin content (CHr) and (b) mean cellular volume (MCV) at 4 mo by generalized additive models. The dose-response curves are shown as solid lines, with $95 \%$ confidence intervals as stippled lines. 
numbers of all three hematological cell lines increased equally in both groups despite a persistent cobalamin biomarker profile in the controls. This finding may indicate that cell replication is prioritized in a growing infant and that the cobalamin needed for this function is provided, despite a biomarker profile of moderate cobalamin deficiency. In support of this hypothesis

Table 4. Hematological parameters according to gender at $6 \mathrm{wk}$ and 4 mo

\begin{tabular}{|c|c|c|c|c|}
\hline & & Girls & Boys & $P$ value \\
\hline \multirow[t]{2}{*}{$N$} & $6 w k$ & 51 & 56 & \\
\hline & $4 \mathrm{mo}$ & 47 & 55 & \\
\hline \multirow{3}{*}{$\begin{array}{l}\text { Hemoglobin, } \\
\text { g/dl }\end{array}$} & $6 \mathrm{wk}$ & $13.3(1.8)$ & $12.7(1.9)$ & 0.09 \\
\hline & $4 \mathrm{mo}$ & $12.0(0.9)$ & $12.1(0.9)$ & 0.45 \\
\hline & $P$ value $^{\mathrm{b}}$ & $<0.001$ & 0.02 & \\
\hline \multirow{3}{*}{$\begin{array}{l}\text { Erythrocytes, } \\
\times 10^{12} / /\end{array}$} & $6 w k$ & $4.08(0.49)$ & $3.93(0.54)$ & 0.13 \\
\hline & $4 \mathrm{mo}$ & $4.27(0.36)$ & $4.46(0.34)$ & 0.009 \\
\hline & $P$ value $^{b}$ & 0.03 & $<0.001$ & \\
\hline \multirow{3}{*}{$\begin{array}{l}\text { Mean cellular } \\
\text { volume, } \mathrm{fl}\end{array}$} & $6 w k$ & $97.5(4.6)$ & $95.0(4.1)$ & 0.005 \\
\hline & $4 \mathrm{mo}$ & $84.0(3.3)$ & $82.2(3.1)$ & $<0.001$ \\
\hline & $P$ value $^{\mathrm{b}}$ & $<0.001$ & $<0.001$ & \\
\hline \multirow{3}{*}{$\begin{array}{l}\text { Reticulocytes, } \\
\times 10^{12} /^{c}\end{array}$} & $6 w k$ & $0.034(0.017)$ & $0.048(0.019)$ & 0.007 \\
\hline & $4 \mathrm{mo}$ & $0.059(0.014)$ & $0.058(0.012)$ & 0.27 \\
\hline & $P$ value $^{\mathrm{b}}$ & $<0.001$ & 0.01 & \\
\hline \multirow{3}{*}{$\begin{array}{l}\text { Reticulocyte } \\
\text { hemoglobin } \\
\text { content, pg }\end{array}$} & $6 w k$ & $32.5(1.4)$ & $31.7(1.5)$ & 0.04 \\
\hline & $4 \mathrm{mo}$ & $30.0(1.1)$ & $29.2(1.5)$ & 0.07 \\
\hline & $P$ value $^{\mathrm{b}}$ & $<0.001$ & $<0.001$ & \\
\hline \multirow{3}{*}{$\begin{array}{l}\text { Leukocytes, } \\
\times 10^{9} / /\end{array}$} & $6 w k$ & $8.9(1.9)$ & $8.9(2.4)$ & 0.92 \\
\hline & $4 \mathrm{mo}$ & $9.6(2.3)$ & $9.4(3.0)$ & 0.28 \\
\hline & $P$ value $^{\mathrm{b}}$ & 0.11 & 0.10 & \\
\hline \multirow{3}{*}{$\begin{array}{l}\text { Platelets, } \\
\times 10^{9} / l\end{array}$} & $6 w k$ & $468(138)$ & $452(126)$ & 0.54 \\
\hline & $4 \mathrm{mo}$ & $543(125)$ & $496(106)$ & 0.04 \\
\hline & $P$ value $^{b}$ & 0.01 & 0.01 & \\
\hline
\end{tabular}

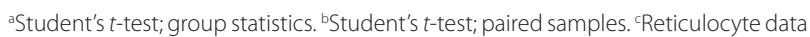
were available for 63 infants at 6 wk ( 29 girls and 34 boys) and 74 infants at 4 mo (34 girls and 40 boys). is a study of 84 Egyptian infants born to mothers with a low median serum cobalamin level (152 pmol/l) in which neither maternal nor infant cobalamin levels had any effect on growth velocity during the first 6 mo of life (17). Although severe cobalamin deficiency has been associated with growth retardation, affecting weight, length, and head circumference $(4,18)$, case reports on moderate cobalamin deficiency in infants often state that the child has a normal weight and may even be obese, the main symptoms being subtle neurological signs and a delayed psychomotor development (19).

At $4 \mathrm{mo}$, high postnatal weight gain and male gender were the main determinants of hematological parameters, and both were associated with a lower iron status. A rapid growth with subsequent higher nutritional needs may cause problems if the diet is nonoptimal. The majority $(70 \%)$ of these infants were exclusively breastfed from birth, and although breast milk is energy rich, it is low in some nutrients, such as iron and vitamins D and K (20). Declining concentrations of iron and cobalamin in breast milk have been reported during the lactation period $(21,22)$, and prolonged exclusive breastfeeding is associated with an increased risk of both cobalamin and iron deficiency (23). Male gender is also a recognized risk factor for iron deficiency in young infants $(24,25)$. Boys have been reported to have significantly lower $\mathrm{MCV}$ and $\mathrm{Hb}$ and ferritin levels as compared with the girls during the first 9 mo of life (24), but the mechanism behind this gender difference is unknown. Gender difference may be partly explained by a higher weight increase in boys, which could, however, not be confirmed in our study; male gender and percentage weight increase appeared to be independent risk factors for low iron status.

In these young infants, the number of reticulocytes was inversely correlated to $\mathrm{Hb}$ level and associated with low MCV and CHr, indicators of an iron-restricted erythropoiesis (26). Contrary to adults, in whom a low Hb level due to iron deficiency is usually associated with a normal or decreased number of erythrocytes (27), a high erythrocyte count was seen in infants aged 6-48 mo with iron deficiency anemia (28). The reticulocytosis observed in this age group was more pronounced in mild vs. severe anemia, explained by the fact that a

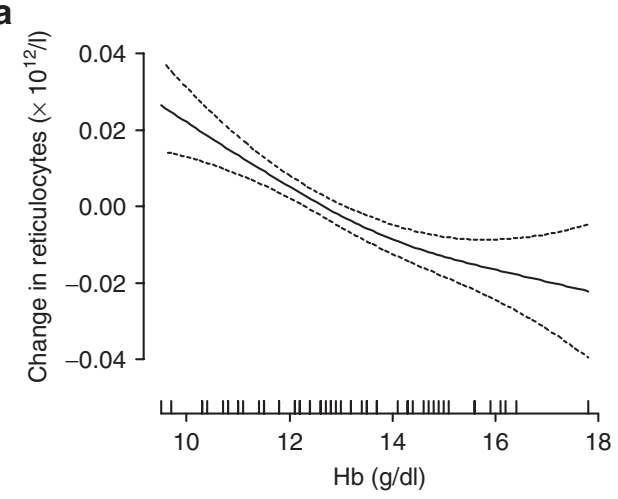

b

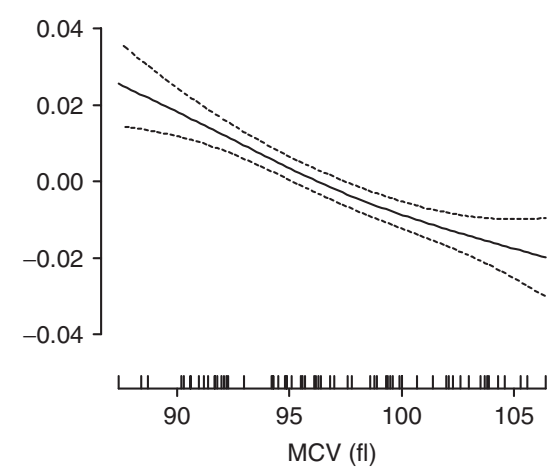

c

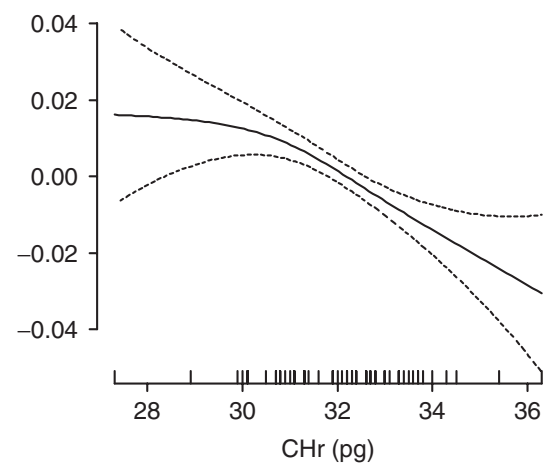

Figure 2. Dose-response relationship between (a) hemoglobin level $(\mathrm{Hb}),(\mathbf{b})$ mean cellular volume (MCV), and (c) reticulocyte hemoglobin content $(\mathrm{CHr})$ with reticulocyte count at $6 \mathrm{wk}$ by generalized additive models. The dose-response curves are shown as solid lines, with $95 \%$ confidence intervals as stippled lines. 
severe iron deficiency is associated with dyserythropoiesis, which may reduce the number of surviving erythrocytes (28).

\section{Conclusion}

In infants with biochemical signs of impaired cobalamin function, cobalamin supplementation at $6 \mathrm{wk}$ had a pronounced effect on intracellular metabolic markers of cobalamin status but had no effects on hematological parameters at $4 \mathrm{mo}$. In these mainly breastfed infants, a high percentage weight gain and male gender were the main determinants of hematological parameters and were associated with a lower iron status at 4 mo. Further studies on micronutrient status in young, mainly breastfed infants are warranted.

\section{METHODS}

\section{Study Population and Design}

Between December 2004 and April 2006, 107 healthy 6-wk-old infants, including three pairs of twins, and their 104 mothers were recruited from a local health service in Bergen, Norway, and enrolled in a cobalamin intervention study. A detailed description of study methods and results have been published (9). Hematological data were available for 107 infants at $6 \mathrm{wk}$ and 102 infants at $4 \mathrm{mo}$, and these children were included in this analysis.

A questionnaire on infant and maternal nutrition, vitamin supplementation, growth parameters, parity, and maternal use of tobacco was completed at $6 \mathrm{wk}$ and $4 \mathrm{mo}$. Because all the various types of formula and porridge used contained iron, infant nutrition was defined as exclusively breastfed vs. nonexclusively breastfed, which included combined breastfeeding and formula feeding, exclusive formula feeding, and either of these combined with solid food.

Infants were assigned by block randomization to receive an intramuscular injection of $400 \mu \mathrm{g}$ hydroxycobalamin (Vitamin B12 Depot; Nycomed Pharma, Asker, Norway) ( $n=54$, cobalamin group) or no treatment ( $n=53$, control group). The laboratory personnel responsible for blood sampling and analyses were blinded to group assignment.

Ethical approval of the protocol was granted by the regional committee on medical research ethics, and the mothers gave written, informed consent. This trial is registered with ClinicalTrials.gov, number NCT00479479.

\section{Blood Sample Collection and Biochemical Analyses}

Blood samples were obtained at $6 \mathrm{wk}$ and $4 \mathrm{mo}$ by antecubital venipuncture and collected into EDTA Vacutainer Tubes (Becton Dickinson, Franklin Lakes, NJ). Hematological parameters (Hb, MCV, erythrocytes, red blood cell distribution width, $\mathrm{CHr}$, leukocytes, and platelets) were analyzed within $4 \mathrm{~h}$ with an automated hematology analyzer (ADVIA 120; Bayer Diagnostics, Tarrytown, NY). Reticulocyte indexes (reticulocytes and CHr) were available for a subpopulation of the study group ( $n=62$ of 107 at $6 \mathrm{wk}, n=72$ of 102 at $4 \mathrm{mo}$, and $n=58$ of 102 paired data for $6 \mathrm{wk}$ and $4 \mathrm{mo}$ ).

The blood samples used for the preparation of EDTA-plasma were placed in ice water, and plasma was separated within $4 \mathrm{~h}$. Plasma levels of tHcy and methylmalonic acid were assayed using a gas chromatography-mass spectrometry method based on methylchloroformate derivatization (29). Serum was obtained by collecting blood into Vacutainer tubes with no additive (Becton Dickinson). Serum cobalamin was determined by a Lactobacillus leichmannii microbiological assay (30) and serum folate by a Lactobacillus casei microbiological assay (31).

\section{Statistical Analysis}

Results are presented as median and interquartile range and mean and SD. Medians were compared by Wilcoxon's signed-rank test and Mann-Whitney $U$-test, and means with Student's $t$-test. Differences in categorical variables were tested with the $\chi^{2}$ test.
Spearman's correlation was used to assess the relation between percentage weight gain and birth weight and the relations between hematological parameters at $6 \mathrm{wk}$ and 4 mo. Multiple linear regression models were used to assess the relations of infant hematological parameters ( $\mathrm{Hb}, \mathrm{MCV}$, and $\mathrm{CHr}$ ) at 4 mo with cobalamin intervention, gender, percentage weight increase from birth to $4 \mathrm{mo}$, infant nutrition, and maternal use of iron supplements from $6 \mathrm{wk}$ to $4 \mathrm{mo}$.

Graphical illustrations of the dose-response relationships of $\mathrm{Hb}$ level, MCV, and $\mathrm{CHr}$ with reticulocyte count at $6 \mathrm{wk}$, and of percentage weight gain with $\mathrm{CHr}$ and MCV at 4 mo were obtained by generalized additive models.

Generalized additive models were computed using the software mgcv-package (version 1.4-1) in R (The R Foundation for Statistical Computing, version 2.8.1; Vienna, Austria), and the SPSS statistical package (version 18) was used for the remaining statistical analyses. Two-sided $P$ values $<0.05$ were considered statistically significant.

\section{ACKNOWLEDGMENTS}

Parts of this study have been published in Bjørke-Monsen AL, Torsvik I, Saetran H, Markestad T, Ueland PM. Common metabolic profile in infants indicating impaired cobalamin status responds to cobalamin supplementation, Pediatrics 2008;122:83-91. We thank the staff at Oasen, Sotra, Olsvik, Varden, and Bønes Helsestasjon and all the mothers and infants who participated in the study.

\section{STATEMENT OF FINANCIAL SUPPORT}

The study was supported by grants from the Norwegian Women's Public Health Association, the Norwegian Foundation for Health and Rehabilitation, and the Foundation to Promote Research into Functional Vitamin B12 deficiency. The sponsors of the study had no role in study design, data collection, data analysis, data interpretation, and writing of the report or in the decision to submit the paper for publication. The corresponding author had full access to all the data in the study and had final responsibility for the decision to submit for publication.

Disclosure: The authors have indicated that they have no financial relationships relevant to this article to disclose. P.M.U. and A.-L.B.-M. are members of the steering board of the nonprofit Foundation to Promote Research Into Functional Vitamin B12 Deficiency. No other potential conflict of interest relevant to this article was reported.

\section{REFERENCES}

1. Dewey KG, Brown KH. Update on technical issues concerning complementary feeding of young children in developing countries and implications for intervention programs. Food Nutr Bull 2003;24:5-28.

2. Biørke-Monsen AL, Ueland PM. Cobalamin status in children. J Inherit Metab Dis 2011;34:111-9.

3. Milman N. Anemia-still a major health problem in many parts of the world! Ann Hematol 2011;90:369-77.

4. Dror DK, Allen LH. Effect of vitamin B12 deficiency on neurodevelopment in infants: current knowledge and possible mechanisms. Nutr Rev 2008;66:250-5.

5. Honzik T, Adamovicova M, Smolka V, Magner M, Hruba E, Zeman J. Clinical presentation and metabolic consequences in 40 breastfed infants with nutritional vitamin B(12) deficiency - What have we learned? Eur J Paediatr Neurol 2010;15:377.

6. Monsen AL, Refsum H, Markestad T, Ueland PM. Cobalamin status and its biochemical markers methylmalonic acid and homocysteine in different age groups from 4 days to 19 years. Clin Chem 2003;49:2067-75.

7. Brugnara C, Zurakowski D, DiCanzio J, Boyd T, Platt O. Reticulocyte hemoglobin content to diagnose iron deficiency in children. JAMA 1999;281:2225-30.

8. Bjørke Monsen AL, Ueland PM, Vollset SE, et al. Determinants of cobalamin status in newborns. Pediatrics 2001;108:624-30.

9. Bjørke-Monsen AL, Torsvik I, Saetran H, Markestad T, Ueland PM. Common metabolic profile in infants indicating impaired cobalamin status responds to cobalamin supplementation. Pediatrics 2008;122:83-91.

10. Proytcheva MA. Issues in neonatal cellular analysis. Am J Clin Pathol 2009;131:560-73. 


\section{Articles | Jenssen et al.}

11. Stockman JA 3rd, Oski FA. Erythrocytes of the human neonate. Curr Top Hematol 1978;1:193-232.

12. Brugnara C, Laufer MR, Friedman AJ, Bridges K, Platt O. Reticulocyte hemoglobin content (CHr): early indicator of iron deficiency and response to therapy. Blood 1994;83:3100-1.

13. Yetley EA, Pfeiffer CM, Phinney KW, et al. Biomarkers of vitamin B-12 status in NHANES: a roundtable summary. Am J Clin Nutr 2011;94:313S21S.

14. Carmel R, Agrawal YP. Failures of cobalamin assays in pernicious anemia. N Engl J Med 2012;367:385-6.

15. Allen RH, Stabler SP, Savage DG, Lindenbaum J. Metabolic abnormalities in cobalamin (vitamin B12) and folate deficiency. FASEB J 1993;7:1344-53.

16. Das KC, Herbert V. Vitamin B12-folate interrelations. Clin Haematol 1976;5:697-745.

17. Hussein L, Abdel Aziz S, Tapouzada S, Boehles H. Serum vitamin B(12) concentrations among mothers and newborns and follow-up study to assess implication on the growth velocity and the urinary methylmalonic acid excretion. Int J Vitam Nutr Res 2009;79:297-307.

18. Graham SM, Arvela OM, Wise GA. Long-term neurologic consequences of nutritional vitamin B12 deficiency in infants. J Pediatr 1992;121(5 Pt 1):710-4.

19. Wighton MC, Manson JI, Speed I, Robertson E, Chapman E. Brain damage in infancy and dietary vitamin B12 deficiency. Med J Aust 1979;2:1-3.

20. Fomon SJ, Strauss RG. Nutrient deficiencies in breast-fed infants. N Engl J Med 1978;299:355-7.

21. Craft IL, Matthews DM, Linnell JC. Cobalamins in human pregnancy and lactation. J Clin Pathol 1971;24:449-55.
22. Siimes MA, Vuori E, Kuitunen P. Breast milk iron-a declining concentration during the course of lactation. Acta Paediatr Scand 1979;68:29-31.

23. Thorisdottir AV, Thorsdottir I, Palsson GI. Nutrition and iron status of 1 -year olds following a revision in infant dietary recommendations. Anemia 2011;2011:986303.

24. Domellöf M, Lönnerdal B, Dewey KG, Cohen RJ, Rivera LL, Hernell O. Sex differences in iron status during infancy. Pediatrics 2002;110: 545-52.

25. Tamura T, Hou J, Goldenberg RL, Johnston KE, Cliver SP. Gender difference in cord serum ferritin concentrations. Biol Neonate 1999;75:343-9.

26. Goodnough LT, Nemeth E, Ganz T. Detection, evaluation, and management of iron-restricted erythropoiesis. Blood 2010;116:4754-61.

27. Wallerstein RO Jr. Laboratory evaluation of anemia. West J Med 1987; 146:443-51.

28. Aslan D, Altay C. Incidence of high erythrocyte count in infants and young children with iron deficiency anemia: re-evaluation of an old parameter. J Pediatr Hematol Oncol 2003;25:303-6.

29. Windelberg A, Arseth O, Kvalheim G, Ueland PM. Automated assay for the determination of methylmalonic acid, total homocysteine, and related amino acids in human serum or plasma by means of methylchloroformate derivatization and gas chromatography-mass spectrometry. Clin Chem 2005;51:2103-9.

30. Kelleher BP, Broin SD. Microbiological assay for vitamin B12 performed in 96-well microtitre plates. J Clin Pathol 1991;44:592-5.

31. Broin SD, Kelleher BP, McCann SR, Ryder RJ, Scott JM. The value of the erythrocyte indices as a screening procedure in predicting nutritional deficiencies. Clin Lab Haematol 1990;12:247-55. 